\title{
PENGEMBANGAN PERPUSTAKAAN MELALUI APLIKASI TEKNOLOGI INFORMASI DAN PENINGKATAN PARTISIPASI MAHASISWA
}

\author{
Siti Zulaikha
}

\begin{abstract}
This research aimed to find out the development of the Faculty of Education (FIP) Library in the State University of Jakarta (UNJ) in terms of the role of the Faculty Library in supporting the learning activities at the Faculty of Education, efforts done to develop the Faculty Library, the application of information technology and the students' participation. To meet its purposes this research was conducted at the Faculty of Education (FIP) of the UNJ within 4 months with the samples covering 120 respondents selected from FIP students by random sampling technique. Research results showed that the FIP Library has not been managed properly. Although the Library facilities are quite complete, they are not well benefitted, the information technology is not much used to develop the Library and the students' participation is seemingly low. The research provides a number of suggestions to develop the FIPLibrary.
\end{abstract}

Key words: faculty library, information technology, students'participation.

\begin{abstract}
Abstrak
Penelitian ini bertujuan untuk mengetahui perkembangan Fakultas Ilmu Pendidikan (FIP) Perpustakaan di Universitas Negeri Jakarta (UNJ) dalam hal peran Perpustakaan Fakultas dalam mendukung kegiatan belajar di Fakultas Ilmu Pendidikan, upaya dilakukan untuk mengembangkan Perpustakaan Fakultas, penerapan teknologi informasi dan partisipasi siswa. Untuk memenuhi tujuan tersebut penelitian ini dilakukan di Fakultas Ilmu Pendidikan (FIP) dari UNJ dalam waktu 4 bulan dengan sampel 120 responden yang mencakup dipilih dari siswa FIP dengan teknik random sampling. Hasil penelitian menunjukkan bahwa Perpustakaan FIP belum dikelola dengan baik. Meskipun fasilitas Perpustakaan yang cukup lengkap, mereka tidak menguntungkan dengan baik, teknologi informasi tidak banyak digunakan untuk mengembangkan Perpustakaan dan partisipasi siswa yang tampaknya rendah. Penelitian ini memberikan beberapa saran untuk mengembangkan perpustakaan FIP.
\end{abstract}

Kata kunci: fakultas perpustakaan, teknologi informasi, partisipasi peserta didik

\section{PENDAHULUAN}

\section{Latar Belakang Masalah}

Perpustakaan sebagai wadah yang menyedia-kan berbagai referensi dan koleksi sumber informasi merupakan sentral rujukan untuk pengembangan ilmu pengetahuan bagi mahasiswa, peneliti, dosen, maupun kaum akademisi. Perpustakaan juga merupakan bagian integral dari proses pendidikan yang menyaji-kan berbagai jenis bahan pustaka untuk menunjang proses pembelajaran. Proses pembelajaran terjadi dengan dipelajarinya hal-hal yang baru serta mengajak pengguna perpustakaan berpikir, mencari, menemu-kan, mengolah, dan mengumpulkan sendiri melalui bacaan yang tersedia di perpustakaan.

Secara eksplisit dalam Undang-undang Nomor 43 Tahun 2007 disebutkan bahwa perpustakaan meru-pakan institusi pengelola koleksi karya tulis, karya cetak, dan/atau karya rekam secara profesional dengan sistem yang baku guna memenuhi kebutuhan pendidikan, penelitian, pelestarian, informasi, dan rekreasi para pemustaka dengan tujuan untuk membe-rikan layanan kepada pemustaka, untuk meningkat-kan kegemaran membaca, serta memperluas wawasan dan pengetahuan untuk mencerdaskan kehidupan bangsa.

Keberadaan perpustakaan di perguruan tinggi juga memiliki fungsi edukasi sangat menonjol, karena layanan perpustakaan harus diusahakan untuk mensukseskan proses belajar mengajar di perguruan tinggi. Agar perpustakaan perguruan tinggi dapat ber-fungsi sebagai pusat informasi, edukasi, dan rekreasi, maka perpustakaan perlu dipromosikan kepada seluruh civitas akademika. Mempromosikan perpusta-kaan bertujuan untuk memperkenalkan perpustakaan, koleksi, jenis koleksi, kekhususan koleksi, jenis laya-nannya dan manfaat yang dapat diperoleh pengguna perpus- 
takaan. Di samping itu, perlu juga dilakukan beberapa hal yang diharapkan dapat menggairahkan minat baca serta menambah jumlah orang yang gemar membaca agar koleksi perpustakaan dapat dimanfaat-kan secara maksimal yaitu dengan antara lain: (1) memilih bahan bacaan yang menarik bagi pengguna perpustakaan, (2) menganjurkan berbagai cara penya-jian kuliah yang dikaitkan dengan tugas-tugas di perpustakaan, (3) memberikan kemudahan dalam men-dapatkan bacaan yang menarik untuk pengguna perpustakaan; (4) memberi kebebasan membaca secara leluasa kepada mahasiswa, (5) memberikan penghar-gaan kepada mahasiswa yang paling banyak memin-jam buku dan tepat mengembalikan buku tersebut di perpustakaan dalam kurun waktu tertentu, (6) per-pustakaan perlu dikelola dengan baik agar pengguna merasa betah dan kerasan berkunjung ke perpusta-kaan.

Hal yang juga harus diperhatikan adalah perkembangan dunia perpustakaan, dari segi data dan dokumen yang disimpan. Dimulai dari perpus-takaan tradisional yang hanya terdiri dari kumpulan koleksi buku tanpa katalog, kemudian muncul perpus-takaan semi modern yang menggunakan katalog (index). Perkembangan mutakhir adalah munculnya perpustakaan digital (digital library) yang memiliki keunggulan dalam kecepatan pengaksesan karena berorientasi ke data digital dan media jaringan kompu-ter (internet). Di sisi lain, dari segi manajemen (teknik pengelolaan), dengan semakin kompleksnya koleksi perpustakaan, saat ini muncul kebutuhan akan peng-gunaan teknologi informasi untuk otomatisasi business process di perpustakaan. Sistem yang dikembangkan kemudian terkenal dengan sebutan sistem otomasi perpustakaan (library automation system).

Penerapan teknologi informasi telah menyebar hampir di semua bidang, tidak terkecuali di bidang perpustakaan. Dengan demikian, ukuran perkemba-ngan perpustakaan banyak diukur dari penerapan teknologi informasi yang digunakan dan bukan dari skala ukuran lain seperti besarnya gedung perpusta-kaan yang dimiliki, jumlah koleksi yang tersedia maupun jumlah penggunanya. Kebutuhan akan tek-nologi informasi sangat berhubungan dengan peran perpustakaan sebagai kekuatan dalam penyebaran informasi ilmu pengetahuan dan kebudayaan.

Untuk itu agar tetap mampu berperan optimal, perpustakaan harus terus berbenah diri yaitu antara lain dengan memanfaatkan kecanggihan teknologi informasi, strategi pengelolaan yang efektif dan dimun-culkannya kebijakan pimpinan sebagai bentuk komit-men pemimpin dalam upaya mengoptimalkan dan meningkatkan peran perpustakaan sebagai pen- gelola sumber daya informasi.

Berdasarkan pemaparan di atas maka diperlu-kan suatu penelitian tentang strategi pengelolaan dan pengembangan perpustakaan agar mampu optimal dalam menjalankan perannya sebagai penyedia berba-gai referensi, koleksi sumber informasi, dan sentral rujukan untuk pengembangan ilmu pengetahuan bagi mahasiswa, peneliti, dosen, maupun kaum akademisi.

\section{Identifikasi Masalah}

Berdasarkan uraian di atas, maka masalah dapat diidentifikasi sebagai berikut.

1. Bagaimanakah kondisi perpustakaan Fakultas Ilmu Pendidikan UNJ saat ini?

2. Bagaimana peran perpustakaan fakultas dalam penunjang kegiatan proses pembelajaran di Fakultas Ilmu Pendidikan UNJ?

3. Apakah penerapan teknologi informasi perlu dilakukan di perpustakaan Fakultas Ilmu Pendidikan UNJ?

4. Bagaimana upaya pengembangan perpustakaan Fakultas Ilmu Pendidikan UNJ?

\section{Perumusan Masalah}

Setelah di identifikasi, maka rumusan masalah yang akan menjadi kajian dalam penelitian ini adalah bagaimanakah upaya pengembangan perpustakaan Fakultas Ilmu Pendidikan UNJ?

\section{Tujuan Penelitian dan Manfaat Penelitian}

Kegiatan penelitian ini ditujukan untuk mem-peroleh secara empiris mengenai sebagai berikut.

1. Peran perpustakaan dalam menunjang kegiatan proses pembelajaran pada Fakultas Ilmu Pendidi-kan.

2. Jenis upaya yang dilakukan untuk pengembangan perpustakaan fakultas.

3. Aplikasi teknologi informasi bagi pengembangan perpustakaan fakultas.

4. Partisipasi mahasiswa dalam pengembangan perpustakaan fakultas.

Adapun manfaat dari kegiatan penelitian ini sebagai berikut.

1. Diharapkan dapat dijadikan sebagai masukan bagi pimpinan Fakultas Ilmu Pendidikan dalam mem-buat kebijakan yang berkenaan dengan perpusta-kaan fakultas.

2. Diharapkan dapat dijadikan referensi dalam upaya pengembangan perpustakaan fakultas.

3. Diharapkan dapat menjadi motivasi bagi maha-siswa khususnya dan civitas akademik lainnya untuk turut berpartisipasi dalam pengembangan perpustakaan.

4. Bagi peneliti, kegiatan penelitian ini akan menjadi 
pengujian wawasan, keterampilan mengolah informasi dari berbagai sumber dan mengasah keahlian dalam melakukan penelitian.

5. Diharapkan dapat menambah khazanah karya ilmiah di lingkungan FIP khususnya dan Univer-sitas Negeri Jakarta.

\section{KAJIAN PUSTAKA}

\section{Perpustakaan}

\section{Hakikat Perpustakaan}

Perpustakaan adalah suatu unit kerja dari suatu badan atau lembaga tertentu yang mengelola bahan-bahan pustaka, baik berupa buku-buku maupun bukan yang diatur secara sistematis sebagai sumber informasi oleh setiap pemakainya (Bafadol, 2001: 3). Perpustakaan juga dapat didefinisikan sebagai salah satu organisasi sumber belajar yang menyimpan, mengelola, dan memberikan layanan bahan pustaka baik buku maupun bukan kepada masyarakat tertentu maupun masyarakat umum (Basuki, 1993: 3).

Dalam Undang-undang RI No. 43 Tahun 2007 Pasal 1 disebutkan bahwa perpustakaan adalah institusi pengelola koleksi karya tulis, karya cetak, dan/ atau karya rekam secara profesional dengan sistem yang baku guna memenuhi kebutuhan pendidi-kan, penelitian, pelestarian, informasi, dan rekreasi para pemustaka.

Perpustakaan menurut Harrod yang dikutip oleh Martono (2007: 227), memiliki empat pengertian sebagai berikut.

1. Perpustakaan bermakna suatu koleksi buku-buku dan bahan karya tulis sastra yang dipelihara seba-gai bahan bacaan, pengajaran, dan konsultasi.

2. Perpustakaan bermakna pula tempat, gedung, atau ruangan yang diatur untuk penyimpanan dan penggunaan pustaka, dan lain-lain.

3. Perpustakaan juga berarti buku-buku yang diter-bitkan oleh sebuah penerbit dengan aneka judul.

4. Perpustakaan juga berarti koleksi film, foto, dan koleksi bahan nonprinting (noncetak) seperti pita kaset, disket, pita film hasil kerja komputer, dan program komputer.

Perpustakaan menurut Sumadji (1992: 13) adalah koleksi yang terdiri dari bahan-bahan tertulis, tercetak, ataupun grafis lainnya seperti film, slide, piringan hitam, dan tape dalam sebuah ruangan atau gedung yang diatur dan diorganisasikan dengan sistem tertentu, agar dapat digunakan untuk keperluan belajar, penelitian, pembacaan dan sebagainya. Sedangkan menurut IFIA (International Federation of
Library Association and Institutions) yang dikutip oleh Basuki (1993), perpustakaan merupakan kumpulan bahan tercetak dan noncetak atau sumber informasi dalam komputer yang disusun secara sistematis untuk kepentingan pemakai. Oleh karena itu, untuk bisa memberikan pelayanan secara maksimal perpusta-kaan harus mampu menyajikan informasi yang berguna dan bernilai lebih karena perpustakaan yang baik harus dapat menciptakan sistem pelayanan yang cepat, efektif/friendly, dan manusiawi. Untuk melihat sejauh mana perpustakaan sudah berhasil melaksana-kan tugasnya, memberikan layanan jasa informasi kepada pemakai, sekurang-kurangnya bisa dilihat dari tiga tolak ukur, yakni kelengkapan koleksi yang dimililki perpustakaan, kemudahan penelusuran informasi, dan kualitas informasi yang disajikan.

Untuk dapat dikatakan sebagai perpustakaan menurut Porang (1990), minimal ada empat syarat yang harus dipenuhi, yaitu.

1. Ada masyarakat yang akan menggunakan perpustakaan tersebut.

2. Memiliki bahan pustaka yang dapat memenuhi kebutuhan masyarakat.

3. Memiliki gedung atau ruang dan fasilitas lainnya sebagai tempat penyimpanan bahan pustaka serta tempat membaca dari para pengunjung.

4. Memakai sistem manajemen yang baik untuk mengatur bahan pustaka kepada masyarakat.

Dari beberapa pengertian perpustakaan di atas, dapat diambil kesimpulan bahwa perpustakaan adalah salah satu unit kerja berupa tempat untuk mengumpulkan, menyimpan, mengelola, dan mengatur koleksi bahan pustaka secara sistematis untuk digunakan oleh pengguna sebagai sumber informasi sekaligus sebagai sarana belajar yang menyenangkan. 2. Tujuan dan Fungsi Perpustakaan

Perpustakaan secara umum bertujuan untuk menyerap dan menghimpun informasi, mewujudkan suatu wadah pengetahuan yang terorganisasi, menumbuhkan kemampuan menikmati pengalaman imajinatif, membantu perkembangan kecakapan bahasa dan gaya pikir, mendidik murid agar dapat menggunakan dan memelihara bahan pustaka secara efisien, serta memberikan dasar ke arah studi mandiri.

Adapun fungsi perpustakaan antara lain adalah fungsi edukatif, fungsi informatif, fungsi tanggung jawab administratif, fungsi riset, dan fungsi rekreatif. 3. Proses Pengelolaan Perpustakan

Dalam pengelolaan perpustakaan di dalamnya terdiri atas proses perencanaan, pengorganisasian, penggerakan, dan pengawasan terhadap perpustakan sekolah sehingga perpustakaan dapat digunakan da- 
lam menunjang kegiatan perkuliahan.

\section{a. Perencanaan (Planning)}

Perencanaan merupakan salah satu aspek yang sangat penting dalam proses pengelolaan perpustakan sekolah. Pustakawan harus mampu membuat perenca-naan, baik jangka pendek maupun jangka panjang. Perencanaan ini bertujuan untuk menentukan langkah-langkah operasional yang akan dilakukan. Kebutuhan mahasiswa bervariasi sesuai dengan jenis mata kuliah. Begitupun kebutuhan dosen dan karya-wan harus diperhatikan pula. Oleh karena itu, pusta-kawan harus jeli terhadap kebutuhan-kebutuhan yang diperlukan oleh pengguna perpustakaan.

Bahan pustaka yang disajikan harus dipilih secara cermat dan teliti. Seorang pustakawan harus memperhatikan dengan sungguh-sungguh dalam merencanakan pengadaan bahan-bahan yang menunjang program pengajaran, informasi tentang masalah-masalah pendidikan, dan lain-lain. Bahan atau sumber informasi yang ada di perpustakaan perlu diatur sebaik mungkin sehingga informasi yang dibutuhkan oleh stakeholders dapat diperoleh dengan mudah, cepat, dan akurat.

Untuk meningkatkan fungsi informasi dalam menunjang perkuliahan, perpustakaan harus proaktif dan dapat mengantisipasi kebutuhan pembacanya. Selain merencanakan bahan-bahan perpustakaan, kegiatan lainnya adalah merencanakan anggaran atau keuangan yang diperlukan dalam kurun waktu tertentu. Pustakawan merencanakan anggaran untuk pembelian atau pengadaan koleksi baru, buku-buku berkala, dan lain-lain. Selain untuk membeli buku juga untuk perawatan dan perbaikan koleksi maupun biaya operasional lainnya. Rencana yang telah dibuat ini selanjutnya diajukan kepada kepala sekolah untuk dipertimbangkan dalam menentukan besarnya anggaran perpustakaan.

\section{b. Pengorganisasian}

Pengorganisasian atau pengaturan perpusta-kaan merupakan tanggung jawab seorang pustaka-wan, karena pengorganisasian merupakan aspek manajemen yang menyangkut pada penyusunan organisasi manusia dan bahan-bahan atau materi. Kegiatannya meliputi.

1). Pengaturan pelayanan peminjaman yang efisien kepada stakeholders.

2). Menyediakan sistem yang efisien mengenai pelaya-nan pemesanan bahan atau koleksi yang ada di jurusan.

3). Memberikan sistem yang fleksibel terhadap stake-holders untuk menggunakan perpustakaan.

c. Pelaksanaan
Aspek lain yang perlu diperhatikan adalah pengaturan staf/personal. Staffing adalah kegiatan pengaturan, pemantauan, dan pembinaan staf sesuai dengan tugas dan tanggung jawab yang diberikan berdasarkan kemampuan yang dimiliki. Penerapan aspek ini kurang diperhatikan. Di perpustakaan hanya ada satu hingga dua orang pustakawan, sehingga penerapan aspek ini lebih pada penerapan selfmanage-ment, dalam arti dirinya sebagai pengatur sekaligus yang diatur sehingga harus benar-benar mampu dan berani menerapkan segala situasinya.

d. Pengarahan (Directory)

Pengarahan adalah suatu kegiatan atau usaha untuk mendorong orang lain dalam menerapkan tujuan tertentu yang telah ditetapkan. Pengarahan merupakan tanggung jawab pimpinan perpustakaan agar dapat mendorong staf untuk bekerja secara optimal untuk mencapai tujuan yang telah ditetapkan. Pengarahan ini dilakukan oleh dan untuk pustakawan itu sendiri. Pustakawan melakukan pengarahan pada dirinya sendiri dalam menerapkan tujuan yang telah ditetapkan.

e. Pengawasan (Controlling)

Pengawasan sangat diperlukan oleh pustaka-wan. Pengawasan ini bertujuan agar pekerjaan yang dilakukan sesuai dengan peraturan yang ada. Hal-hal yang perlu diperhatikan dalam aspek pengawasan adalah.

1). Selalu menyadari tujuan yang akan dicapai.

2). Menghindari kegiatan yang tidak efisien.

3). Mengadakan evaluasi kegiatan yang telah dilak-sanakan.

Dengan demikian, jelaslah bahwa manajemen dengan memperhatikan unsur dari setiap aspek di perpustakan memegang peranan yang sangat penting agar tujuan yang telah ditetapkan dapat tercapai dengan baik.

Bentuk lain dari kegiatan pengelolaan perpus-takaan adalah bentuk pelayanan bagi peminat dalam hal ini mahasiswa. Bentuk-bentuk pelayanan tersebut meliputi.

\section{1). Pelayanan Pembaca}

Pelayanan pembaca menjadi tolok ukur bagi keberhasilan kerja pustakawan. Namun tugas layanan tidak mungkin berdiri sendiri tanpa didukung oleh tugas pembinaan koleksi, yang menyangkut penga-daan, pengolahan, dan pemeliharaan koleksi.

2). Pelayanan Peminjaman

Pelayanan peminjaman adalah kegiatan kerja berupa pemberian bantuan kepada pemakai perpusta-kaan dalam proses peminjaman dan pengembalian koleksi pustaka. Kegiatan ini sering disebut dengan 
sirkulasi. Sirkulasi dalam arti mengedarkan koleksi perpustakaan kepada pemakainya. Pustakawan harus pandai menentukan kebijakan dalam mengatur pelayanan yang disesuaikan dengan situasi dan kondisi perpustakaan antara lain.

a. Ruang perpustakaan kecil dan jumlah koleksi terbatas, namun merupakan sumber informasi mutakhir. Situasi ini dapat diatasi dengan membuat persyaratan peminjaman yang dapat menjamin pustaka tidak hilang.

b. Terbatasnya jumlah tenaga perpustakaan. Situasi ini dapat diatasi dengan membatasi waktu pelaya-nan, misalnya tidak setiap hari atau sehari hanya beberapa jam (tidak selama jam kerja).

3). Pelayanan Referensi

Referensi berasal dari bahasa Inggris "to refer" yang artinya menunjuk kepada. Apapun yang ditun-juk baik orang maupun benda sebagai sumber jawaban pertanyaan informasi disebut referensi. Akan tetapi, referensi dibatasi pada informasi yang terekam, seperti buku, majalah, jurnal, dan lain-lain.

Pelayanan referensi merupakan pelayanan lang-sung berupa pemberian bantuan kepada siswa, bantuan tersebut berupa jawaban atas pertanyaan-pertanyaan dengan menggunakan koleksi referensi. Petugas referensi dituntut memiliki kecakapan dalam menganalisis pertanyaan sehingga diharapkan mam-pu menjawab pertanyaan dengan cepat, tepat, dan benar.

4). Status dan Jenis Perpustakaan

Perpustakaan berkembang pesat dari waktu ke waktu menyesuaikan dengan perkembangan pola kehidupan masyarakat, kebutuhan, pengetahuan, dan teknologi informasi. Perkembangan tersebut juga mem-bawa dampak kepada "pengelompokkan" perpusta-kaan berdasarkan pola-pola kehidupan, kebutuhan, pengetahuan, dan teknologi informasi tadi. Istilah-istilah perpustakaan "membengkak" menjadi sangat luas namun cenderung mempunyai sebuah spesifikasi tertentu.

Dilihat dari perkembangan teknologi informa-sinya, perpustakaan berkembang dari perpustakaan tradisional, semi tradisional, elektronik, digital hingga perpustakaan "virtual". Dilihat dari pola kehidupan masyarakat berkembang mulai perpustakaan desa, perpustakaan masjid, perpustakaan pribadi, perpusta-kaan keliling, dan sebagainya.

Kemudian juga dilihat dari perkembangan kebutuhan dan pengetahuan sekarang ini banyak bermunculan istilah perpustakaan umum, perpusta-kaan khusus, perpustakaan anak-anak, perpustakaan sekolah, perpustakaan akademik (perguruan tinggi), perpustakaan perusahaan, dan lain sebagainya.
Namun dari sekian banyak istilah dan jenis perpustakaan tersebut, sebetulnya berdasarkan sifat dan golongan besar perpustakaan secara umum terbagi dalam sebuah bentuk perpustakaan khusus dan perpustakaan umum. Di mana dari kedua perpus-takaan tersebutlah berkembang istilah lain yang disesuaikan dengan cara pengelolaan, pengguna, tuju-an, teknologi yang digunakan, pengetahuan yang dikemas, serta tujuan perpustakaan didirikan.

Perpustakaan khusus merupakan perpusta-kaan yang didirikan untuk mendukung visi dan misi lembaga-lembaga khusus dan berfungsi sebagai pusat informasi khusus terutama berhubungan dengan penelitian dan pengembangan. Biasanya perpustakaan ini berada di bawah badan, institusi, lembaga atau organisasi bisnis, ilmiah, pemerintah, dan pendidikan erawa perguruan tinggi, perusahaan, departemen, asosiasi profesi, instansi pemerintah dan lain sebagai-nya.

Perpustakaan khusus biasanya juga mempu-nyai karakteristik khusus apabila dilihat dari fungsi, subjek yang ditangani, koleksi yang dikelola, pemakai yang dilayani, dan kedudukannya. Dari hal tersebut nantinya akan terlihat dengan jelas perbedaannya dengan perpustakaan-perpustakaan pada umumnya.

\section{Ketenagaan dan Tugas Pengelola Perpustakaan}

Tenaga pengelola perpustakaan merupakan kunci keberhasilan pengelola perpustakaan. Mereka berfungsi sebagai motor penggerak, dinamisator, dan motivator pekerjaan di perpustakaan. Oleh karena itu, dituntut kualifikasi kepribadiannya antara lain.

1. Beriman dan bermoral.

2. Suka membantu, ramah, berwawasan luas, serta suka membaca.

3. Sabar mau menerima kritik dan saran.

4. Inisiatif, kreatif, inovatif, enerjik, serta mampu berko-munikasi lisan dan tertulis.

5. Berpenampilan menarik.

6. Mengetahui fungsi/tugas perpustakaan dan lem-baga induknya.

7. Mengetahui masyarakat lingkungan dan dapat bekerja sama dengan perpustakaan lain.

\section{Teknologi Informasi dalam Pengelolaan Perpus- ta-kaan}

1. Sistem Informasi Manajemen Perpustakaan

A. Hakikat Sistem Informasi Manajemen Perpustakaan

Sistem informasi manajemen merupakan sistem informasi yang menghasilkan hasil keluaran (output) dengan menggunakan masukan (input) dan berbagai proses yang diperlukan untuk memenuhi tujuan tertentu dalam suatu kegiatan manajemen. 
Raymond Mc. Leod Jr (2005: 259) menyebutkan bahwa sistem informasi manajemen didefinisikan sebagai suatu sistem berbasis manajemen yang menye-diakan informasi bagi beberapa pemakai dengan kebutuhan yang serupa.

Gordon B. Davis dalam Rochaety (2005: 12) menyebutkan bahwa sistem informasi manajemen merupakan sebuah sistem manusia dan mesin yang terpadu untuk menyajikan informasi guna mendukung fungsi operasi, manajemen, dan proses pengambilan keputusan dalam sebuah organisasi. Dengan kata lain, sistem informasi manajemen merupakan kesatuan alat dan manusia yang terstruktur dalam sebuah kerangka kerja manajemen dalam mengelola sumber daya infor-masi yang dimiliki organisasi.

Sistem informasi manajemen sangat erat kaitan-nya dengan teknologi komputer. Menurut Azis Wahab, pengadaan perangkat komputer dan pengetahuan pemanfaatannya sudah merupakan sesuatu yang harus terutama dalam memasuki abad ke 21 dan dalam rangka mempersiapkan diri menerima wewenang otonomi pendidikan, paling tidak karena beberapa hal:

a. Informasi yang disimpan secara elektronik memiliki fleksibilitas dalam mengakses dan dalam peman-faatannya yang sudah tidak mungkin dilakukan melalui sistem penanganan informasi dengan cara lama. Komputer juga menyediakan begitu banyak kemudahan dalam mengelola informasi dalam arti menyimpan, mengambil kembali, dan pemutak-hiran informasi.

b. Komputer juga merupakan alat yang memiliki kemampuan luar biasa dalam membantu meman-faatkan informasi itu dalam rangka pengambilan keputusan dan pemecahan masalah secara kreatif.

Kemampuan komputer juga untuk memanipulasi dan menyusun kembali informasi untuk kepenting-an khusus pemakai menjadikannya menjadi alat yang efektif dalam tugas menganalisis dan menaf-sirkan kecenderungan yang terjadi, pengujian hipotesis, dan identifikasi kecenderungan baru program-program fakultas.

c. Dengan menempatkan komputer di bawah kendali langsung kepala sekolah akan menjadi alat yang sangat ampuh untuk pengelolaan dan pemrosesan informasi sebuah kemampuan yang mengantarkan langsung informasi secara cepat kehadapan kepala sekolah dan juga kepada pimpinan lainnya.

d. Komputer sebagai alat untuk memproses informasi, dan memiliki tingkat aplikasi dalam setiap langkah proses manjemen-perencanaan, mengko- munikasi-kan, mengorganisasikan, pengawasan dan memotivasi.

B. Keunggulan Sistem Informasi Manajemen Perpus-takaan

Beberapa keunggulan dalam penggunaan sistem informasi manajemen yaitu.

1. Dapat berbasis web, sehingga mudah digunakan dan mudah disebarluaskan.

2. Mempunyai dua interface, user dan admin

3. Data yang disajikan realtime

4. Nagivasi data sangat mudah

5. Interface sangat sederhana sehingga mudah digunakan oleh siapa saja, dan

6. Mudah dikembangkan sesuai kreativitas

Dalam menggunakan sistem informasi mana-jemen, perangkat yang dibutuhkan terdiri atas software dan hardware. Software yang dibutuhkan Appserv (phpmyadmin, mysql) dan Mozilla Firefox (web browser), sedangkan hardware yang dibutuhkan terdiri atas: 1 buah PC yang digunakan sebagai server, beberapa PC untuk digunakan oleh user, dan jaringan lokal (LAN). C. Prosedur Penggunaan Sistem Informasi Manajemen

Adapun langkah-langkah yang dapat dilaku-kan dalanm menggunakan program sistem informasi manajemen adalah sebagai berikut.

a. Instalasi web server
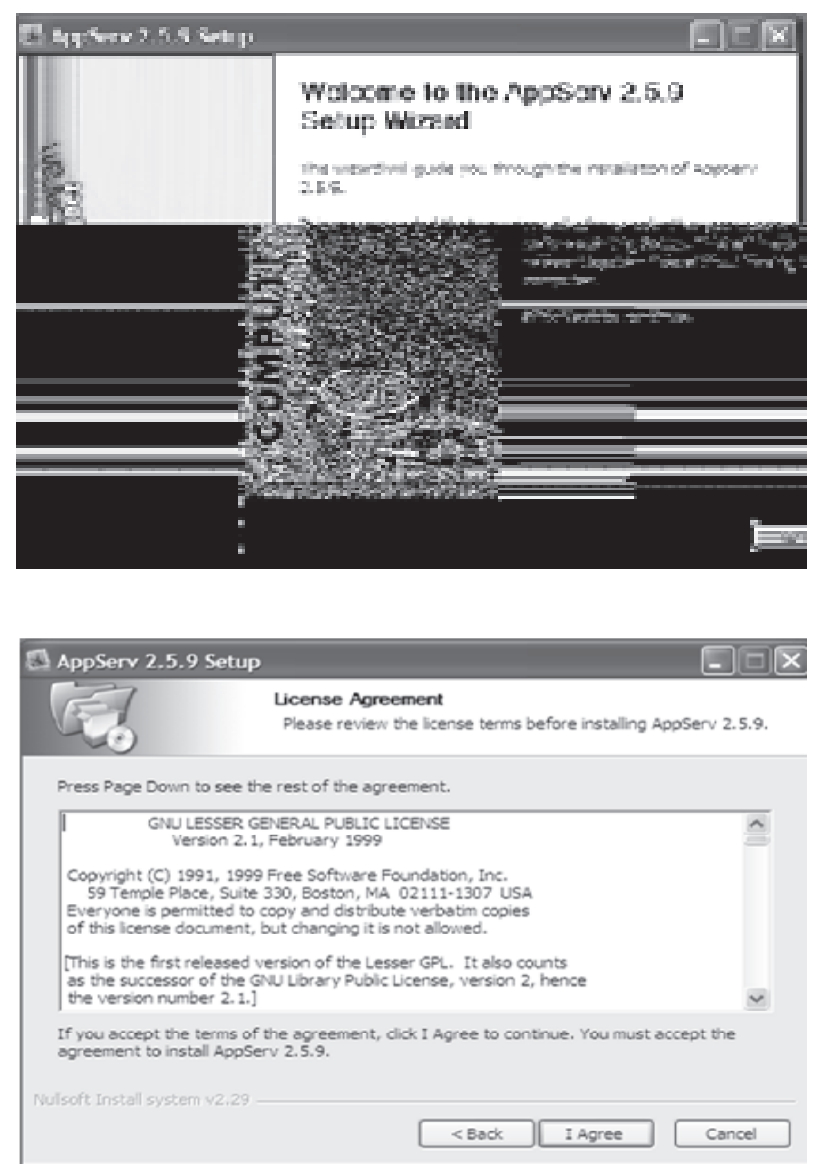

Pilih: I agree 

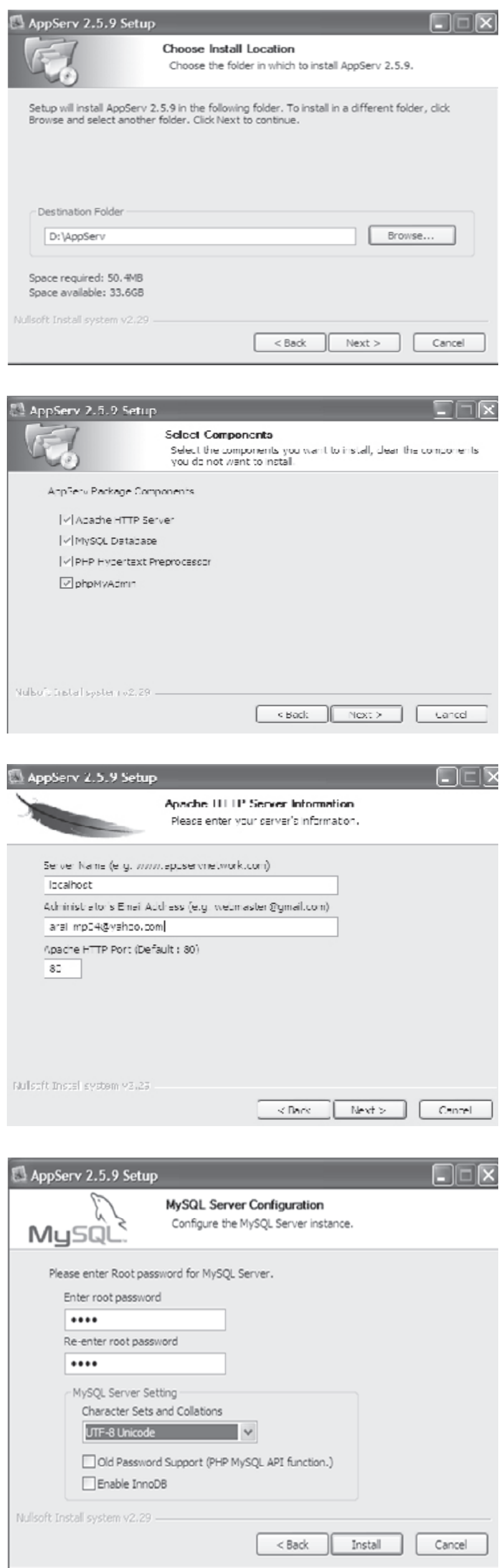

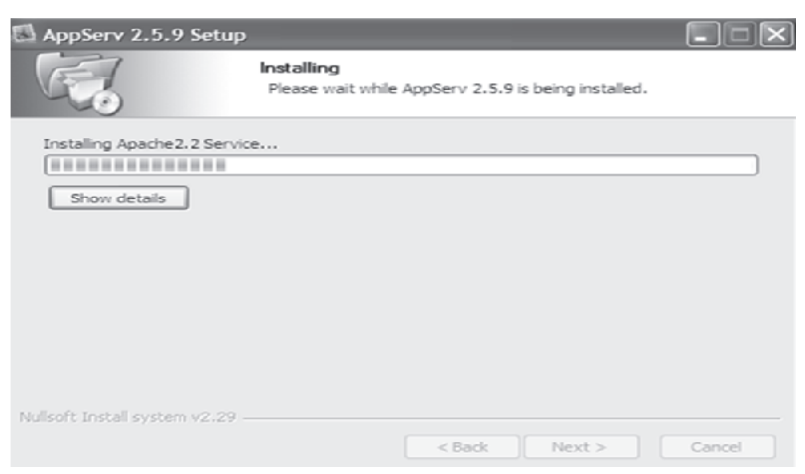

Proses instalasi mulai berjalan

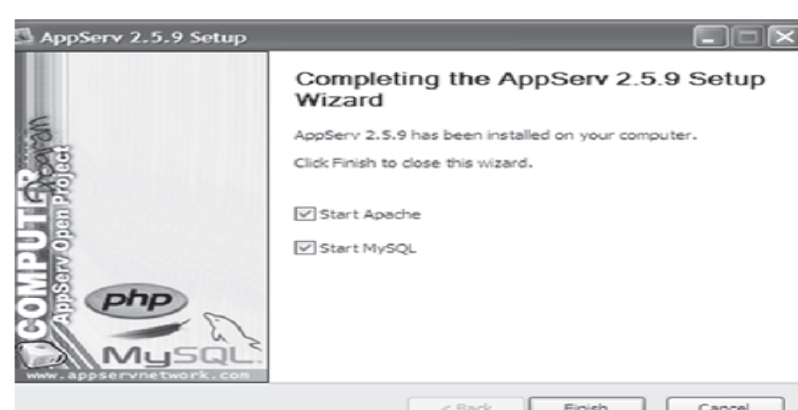

Centang dua opsi yang ada, kemudian tekan finish. Instalasi Web Server Selesai

b. Instalasi Sistem Informasi Manajemen

Copy-kan folder "sinema-pustaka-admin" dan "sinemapustaka-user" ke drive D: \appserve \www $\backslash$.

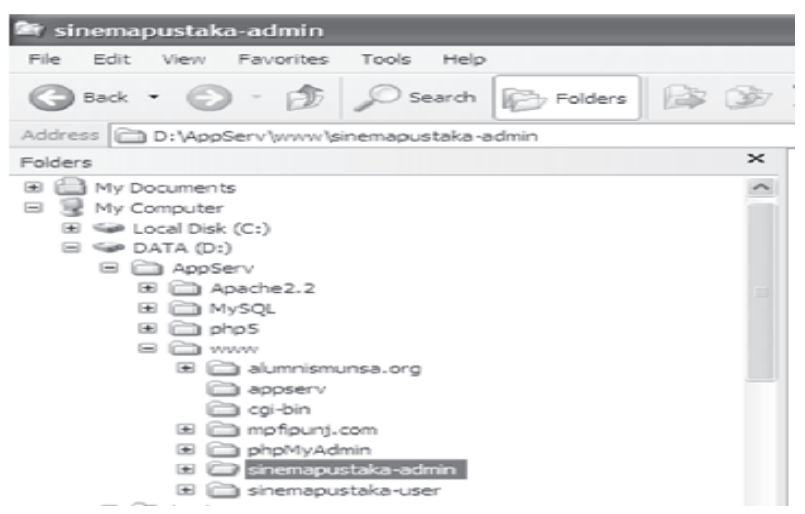

Copy-kan folder "sinema-pustaka" ke drive D: $\backslash$ appserve $\backslash \mathrm{MySQL} \backslash$ data $\backslash$

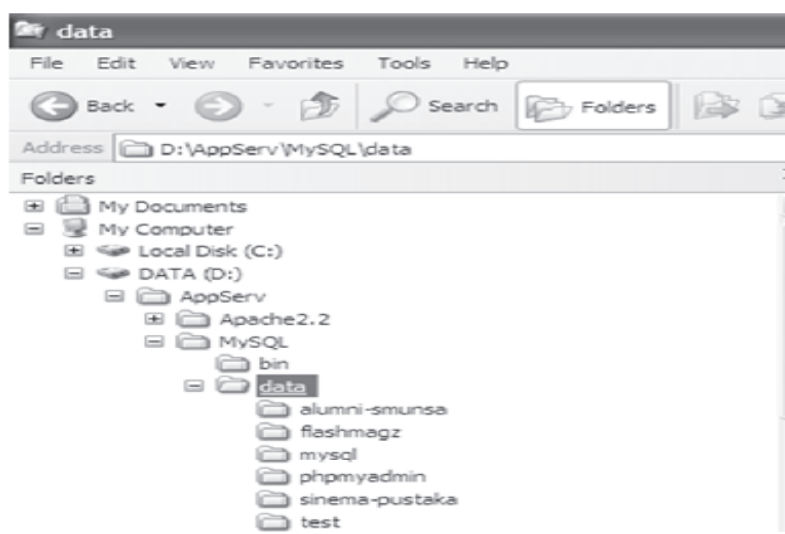

Perspektif Ilmu Pendidikan - Vol.23 Th. XIV April 2011 


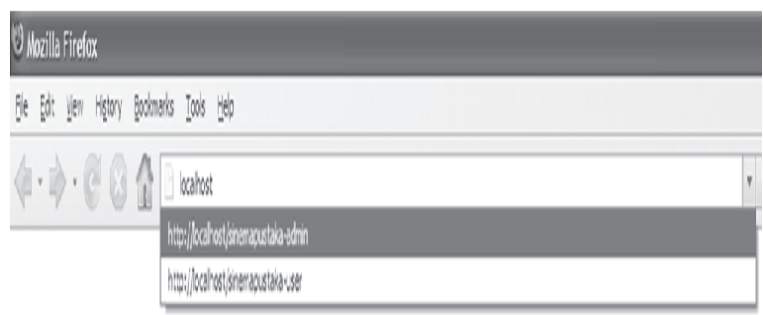

Buka Mozilla firefox, kemudian ketikkan alamat berikut ini pada address bar :

- http://localhost/sinemapustaka-admin (untuk admin)

- http://localhost/sinemapustaka-user (untuk user)

\section{INTERFACE USER}

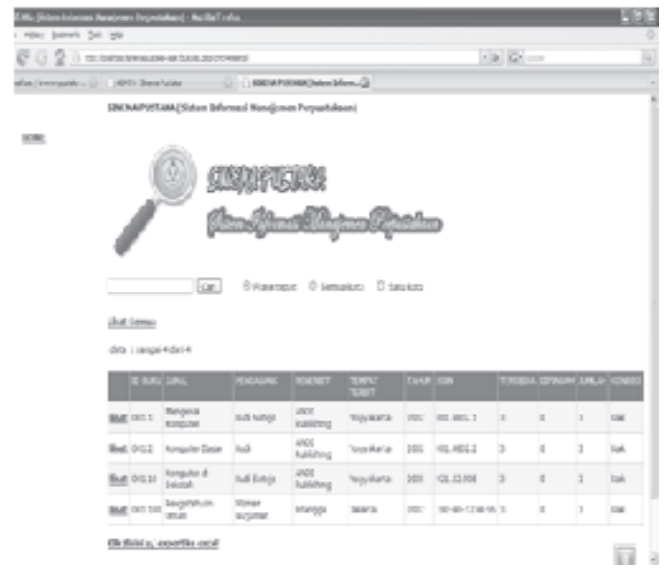

Begitu simple-nya interface user seperti terlihat pada gambar, sehingga user dengan sangat mudah dapat menggunakan aplikasi ini. User cukup mengikuti link-link yang ada pada tampilan.

\section{1) Sistem Otomasi Perpustakaan}

Dari segi manajemen (teknik pengelolaan), dengan semakin kompleksnya koleksi perpustakaan, data peminjam, transaksi dan sirkulasi koleksi perpus-takaan, saat ini muncul kebutuhan akan penggunaan teknologi informasi untuk otomatisasi business process di perpustakaan. Sistem yang dikembangkan dengan pemikiran dasar bagaimana kita melakukan otomati-sasi terhadap berbagai business process di perpustakaan, kemudian terkenal dengan sebutan sistem otomasi perpustakaan (library automation system).

Sistem otomasi perpustakaan yang baik adalah yang terintegrasi, mulai dari sistem pengadaan bahan pustaka, pengolahan bahan pustaka, sistem pencarian kembali bahan pustaka, sistem sirkulasi, membership, pengaturan denda keterlambatan pengembalian, dan sistem reporting aktivitas perpustakaan dengan berba-gai parameter pilihan. Lebih sempurna lagi, apabila sistem otomasi perpustakaan dilengkapi dengan barcoding, dan mekanisme pengaksesan data berbasis web dan internet.
Berikut adalah salah satu contoh sistem otomasi perpustakaan dengan fitur-fitur yang mengakomodasi kebutuhan perpustakaan secara lengkap, dari pengadaan, pengolahan, penelusuran, serta manajemen anggota dan sirkulasi. Diharapkan contoh sistem yang ditampilkan dapat dijadikan studi kasus dalam pengembangan sistem otomasi perpustakaan lebih lanjut.

1. Otentikasi Sistem

Sistem akan melakukan pengecekan apakah username dan password yang dimasukkan adalah sesuai dengan yang ada di database. Kemudian juga mengatur tampilan berdasarkan komputer pemilik account, apakah sebagai pengguna atau admin dari sistem.

a. Menu Utama

Menampilkan berbagai menu pengadaan, pengolahan, penelusuran, anggota dan sirkulasi, erawat peraturan, administrasi, dan security. Menu ini dapat disetting untuk menampilkan menu sesuai dengan hak akses user (sistem), komputer hanya meng-aktifkan menu penelusuran untuk pengguna umum, dan sebagainya.

b. Administrasi, Security, dan Pembatasan Akses

Fitur ini mengakomodasi fungsi untuk mena-ngani pembatasan dan wewenang user, mengelompok-kan user, dan sistem user id serta password. Juga menge-lola dan mengembangkan serta mengatur sendiri akses menu yang diinginkan.

c. Pengadaan Bahan Pustaka

Fitur ini mengakomodasi fungsi untuk pencata-tan permintaan, pemesanan, dan pembayaran bahan pustaka, serta penerimaan dan laporan (reporting) proses pengadaan.

d. Pengolahan Bahan Pustaka

Fitur ini mengakomodasi proses pemasukkan data buku/majalah ke database, penelusuran status buku yang diproses, pemasukkan cover buku/nomor barcode, pencetakan kartu sistem, label barcode, dan nomor punggung buku (call number).

e. Penelusuran Bahan Pustaka

Penelusuran atau pencarian kembali koleksi yang telah disimpan adalah suatu hal yang penting dalam dunia perpustakaan. Fitur ini harus meng-akomodasi penelusuran melalui pengarang, judul, penerbit, subjek, tahun terbit, dan sebagainya.

f. Manajemen Anggota dan Sirkulasi

Ini termasuk jantungnya erawa otomasi perpus-takaan, karena sesungguhnya disinilah banyak kegiatan manual yang digantikan oleh erawatt dengan jalan mengotomasinya. Didalamnya terdapat berbagai fitur diantaranya: pemasukkan dan pencarian data anggota perpustakaan, pencatatan peminjaman dan pengembalian buku (dengan teknologi barcoding), 
penghitungan denda keterlambatan pengembalian buku, dan pemesanan peminjaman buku.

\section{g. Pelaporan (Reporting)}

Sistem reporting yang memudahkan pengelola perpustakaan untuk bekerja lebih cepat, di mana laporan dan rekap dapat dibuat secara otomatis, sesuai dengan parameter-parameter yang dapat diatur. Sangat membantu dalam proses analisis aktivitas perpustakaan, misalnya tidak perlu lagi membuka ribuan transaksi secara manual untuk melihat transaksi peminjaman koleksi dalam satu kategori, atau mengecek aktivitas seorang pengguna perpusta-kaan dalam satu tahun.

2. Partisipasi Mahasiswa

Untuk mengkaji teori tentang partisipasi mahasiswa, peneliti mencoba menggali kajian pustakanya dari konsep partisipasi masyarakat karena mahasiswa juga adalah masyarakat yang menjadi bagian penting dalam komunitas kampus.

Partisipasi bisa diartikan sebagai “ aprocess through which stakeholders influence and share control over development initiatives and the decisions and resources which affect them." (Participation Learning Group Final Report: 2010). Dari pengertian tersebut dapat dilihat bahwa partisipasi harus melibatkan stakeholder yang aktif dan terlibat dalam mempengaruhi dan mengon-trol sesuatu yang memiliki dampak kepada dirinya sendiri.

Partisipasi diartikan juga sebagai proses yang di dalamnya stakeholders turut serta dalam mengambil bagian pada pengambilan keputusan. Partisipasi menurut Rhiti (2005: 98) juga mempunyai arti penting sekurang-kurangnya dalam lima hal berikut 1). sebagai masukan kebijaksanaan, 2). sebagai strategi, 3). sebagai komunikasi, 4) sebagai media pemecahan publik, 5). sebagai terapi sosial dalam arti cara untuk menghi-langkan keterasingan dari warga masyarakat dalam suatu kegiatan pembangunan.

Partisipasi bisa dibedakan ke dalam dua bagian, yaitu 1) partisipasi bebas (spontan dan akibat penyuluhan) dan 2) partisipasi paksaan, sebagai konsekuensi hukum, kondisi sosial ekonomi, dan ke-biasaan setempat. Ada tiga unsur penting dalam definisi tersebut yaitu unsur keterlibatan, kontribusi, dan tanggung jawab. Partisipasi juga mensyaratkan adanya kerjasama dengan banyak pihak. Dalam kerja sama, orang harus mengaktualisasikan diri dengan merealisasikan segenap kemampuannya.

Menurut Koentjaraningrat, terdapat dua jenis partisipasi masyarakat dalam pembangunan, yaitu partisipasi semu dan partisipasi murni. Partisipasi semu merupakan peran serta masyarakat dalam suatu kegiatan atau proyek pembangunan umumnya. Parti- sipasi ini bersifat sementara atau hanya berlang-sung pada saat proyek dilaksanakan. Apabila proyek berakhir, misalnya dana telah habis, maka tidak dilanjutkan secara mandiri.

Partisipasi masyarakat bisa dibedakan berda-sarkan tipologinya menjadi partisipasi kuantitatif dan kualitatif. Partisipasi kuantitatif berkaitan dengan frekuensi keikutsertaan masyarakat terhadap imple-mentasi kebijakan, sedangkan partisipasi kualitatif merujuk kepada tingkat dan derajat partisipasinya. Partisipasi (Mulyasa, 2003: 170) juga bisa dibedakan ke dalam tiga kelompok, yaitu partisipasi mandiri yang merupakan usaha berperan serta yang dilakukan secara mandiri oleh pelakunya, partisipasi mobilisasi, dan partisipasi seremoni.

Uphoff, dalam Nanang (2003: 114) mengemuka-kan bahwa kerangka kerja merekonstruksi partisipasi mengandung tiga dimensi yakni, konteks, tujuan, dan lingkungan yang bisa dilakukan dengan empat langkah proses partisipasi, yaitu 1) partisipasi dalam pengambilan keputusan, 2) partisipasi dalam pelaksa-naan, 3) partisipasi dalam memperoleh manfaat/ keuntungan, dan 4) partisipasi dalam mengevaluasi.

Slamet mengemukakan tentang syarat yang diperlukan agar masyarakat lebih berperan aktif dalam pembangunan, yaitu kemauan, kemampuan, dan kesempatan. Keberadaan kemauan, kemampuan, dan kesempatan bagi masyarakat untuk berpartisipasi dalam proses pembangunan akan dipengaruhi oleh berbagai faktor di seputar kehidupan manusia yang saling berinteraksi satu dengan yang lainnya, terutama faktor-faktor umur,pendidikan (formal maupun informal), kepemimpinan (formal maupun informal), budaya lokal (norma, tradisi dan adat istiadat), serta pengaturan dan pelayanan pemerintahan.

Konsep partisipasi masyarakat yang lebih komprehensif dikemukakan Arnstein (A Ladder of Citizen Participation: 2008), yang membuat tingkatan partisipasi ke dalam delapan tangga partisipasi berda-sarkan kekuatan masyarakat (citizen power) dalam menentukan hasil akhir suatu kegiatan. Delapan tangga partisipasi tersebut adalah 1) manipulasi, 2) terapi, 3) informasi, 4) konsultasi, 5) peredaman, 6) kemitraan, 7) pendelegasian kekuasaan, dan 8) kontrol masyarakat. Tingkatan ke-1 dan 2 dikelompokkan sebagai bukan partisipasi, karena sasarannya hanya untuk membuat masyarakat "dapat diatur" atau sekadar agar tidak merasa diabaikan. Tingkatan ke-3, 4, dan 5 dikelompokkan sebagai partisipasi tokenistik, yakni pengikutsertaan masyarakat terbatas sebagai bentuk penghargaan kepada masyarakat dengan memberikan informasi kepada masyarakat dan mendengarkan 
informasi dari masyarakat, konsultasi publik, atau meredam protes/kemarahan masyarakat, tetapi tidak ada jaminan bahwa aspirasi masyarakat akan menentukan keputusan.

Menurut Arnstein, jika partisipasi dibatasi pada tingkatan ini maka kecil kemungkinan kegiatan yang dikembangkan akan berhasil dengan baik. Tingkatan ke-6, 7, dan 8 digolongkan sebagai tingkat otoritas masyarakat, di mana masyarakat memiliki pengaruh yang menentukan dalam pengambilan keputusan dan dalam menjalankan program kegiatan. Tingkatan inilah yang disebut sebagai partisipasi nyata (real power). Tingkatan partisipasi paling rendah dari kelompok ini adalah kemitraan.

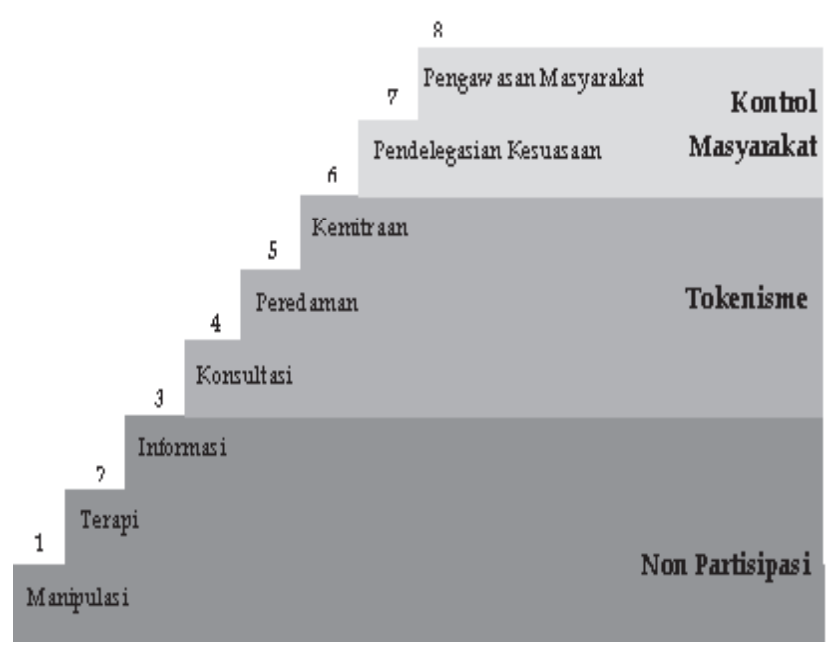

Gambar 1. Tangga-tangga Partisipasi Sumber: Arnstein, S.R. (2008).

Dari paparan teori di atas bisa diartikan bahwa partisipasi mahasiswa adalah keterlibatan mahasiswa dalam memberikan pendukungan, pengontrolan, dan mediasi atas jalannya proses pengelolaan dan pengembangan perpustakaan.

3. Perpustakaan Fakultas Ilmu Pendidikan UNJ

Perpustakaan Fakultas merupakan perpustaka-an khusus yang didirikan untuk mendukung visi dan misi Fakultas dan berfungsi sebagai pusat informasi khusus terutama berhubungan dengan penelitian dan pengembangan. Perpustakaan Fakultas memiliki karakteristik khusus apabila dilihat dari fungsi, subjek yang ditangani, koleksi yang dikelola, pemakai yang dilayani, dan kedudukannya.

Sedemikian penting keberadaan Perpustakaan di suatu Fakultas, maka pimpinan fakultas dan semua pengguna perpustakaan diharapkan dapat mengupa-yakan pengembangan perpustakaan secara berkelan-jutan agar perpustakaan fakultas ini dapat berfungsi maksimal sebagaimana yang diharapkan.

Perpustakaan Fakultas Ilmu Pendidikan dikelo-la oleh seorang petugas perpustakaan yang berlatar belakang D2 Perpustakaan. Petugas bertanggung jawab kepada Pembantu Dekan I. Dalam melaksana-kan tugas dan fungsinya, petugas dibantu oleh satu orang pembantu harian dan membagi dua kegiatan layanan, yaitu layanan teknis dan layanan pemakai. Layanan teknis ini meliputi operator komputer, pengadaan, inventaris, katalogisasi, klasifikasi, penyiapan penyusunan buku di rak, dan pemeliharaan bahan pustaka. Adapun layanan meliputi sirkulasi, referensi, dan bimbingan pemakai.

Perabot dan perlengkapan Perpustakaan FIP UNJ mencakup barang-barang untuk keperluan umum/pengunjung, keperluan untuk memberikan jasa layanan dan kerja petugas seperti meja sirkulasi, rak buku, meja baca, kursi baca, meja petugas, dan komputer.

Koleksi Perpustakaan FIP terdiri dari buku-bu$\mathrm{ku}$, jurnal dan skripsi yang disediakan untuk civitas akademika yaitu mahasiswa, peneliti, dosen maupun kaum akademisi. Dengan harapan dapat membantu keperluan dosen dan mahasiswa terutama yang berkaitan dengan bahan rujukan perkuliahan.

\section{METODOLOGI PENELITIAN}

\section{Tujuan Penelitian}

Kegiatan penelitian ini ditujukan untuk mem-peroleh secara empiris mengenai: Peran Perpustakaan dalam menunjang kegiatan proses pembelajaran pada Fakultas Ilmu Pendidikan, jenis upaya yang dilakukan untuk pengembangan Perpustakaan Fakultas dan Aplikasi Teknologi Informasi bagi pengembangan Per-pustakaan Fakultas.

\section{Metode Penelitian.}

Pendekatan yang digunakan dalam penelitian ini adalah pendekatan survey dan analisis data sekunder dengan metode eksploratif dan deskriptif.

\section{Tempat dan Waktu Penelitian.}

Penelitian dilakukan di Fakultas Ilmu Pendidi-kan FIP UNJ dan waktu yang dibutuhkan dalam penelitian ini selama 4 bulan.

\section{Populasi dan Sampel}

Populasi penelitian ini adalah mahasiswa Fakultas Ilmu Pendidikan yang masih aktif mengikuti perkuliahan dan berasal dari berbagai jurusan yang ada di Fakultas Ilmu Pendidikan, yakni mahasiswa angkatan 2007, 2008, dan 2009. Adapun sampel 
yang diambil dari tiap-tiap angkatan sebanyak 40 respon-den, sehingga total sampel sebanyak 120 responden. Sampel dilakukan dengan teknik random sampling.

\section{Instrumen Penelitian}

Untuk mendapatkan informasi tentang pengem-bangan perpustakaan Fakultas Ilmu Pendidikan, dilakukan melalui wawancara maupun dengan teknik paper and pencil yang dilakukan dengan penyebaran instrumen kepada para responden.

\section{Definisi Objek Penelitian}

Pengembangan Perpustakaan Fakultas Ilmu Pendidikan merupakan kegiatan yang dilakukan dalam rangka meningkatkan peran perpustakaan terutama dalam memberikan layanan perpustakaan yang optimal kepada stakeholders yang meliputi keterse-diaan sarana dan pemanfaatan bahan pustaka, pengelolaan perpustakaan Fakultas Ilmu Pendidikan, dan Penerapan Teknologi Informasi dalam pengelo-laan perpustakaan.

Partisipasi mahasiswa adalah keterlibatan mahasiswa dalam memberikan pendukungan, pengontrolan, dan mediasi atas jalannya proses pengelolaan dan pengembangan perpustakaan.

\section{Teknik Pengumpulan Data.}

Untuk memperoleh data tentang ketersediaan sarana dan pemanfaatan bahan pustaka, pengelolaan perpustakaan Fakultas Ilmu Pendidikan, dan Parti-sipasi Mahasiswa dalam pengembangan perpustaka-an Fakultas Ilmu Pendidikan digunakan angket. Selain itu untuk mendukung keabsahan data, maka ditun-jang dengan wawancara.

\section{Teknik Analisis Data}

Analisis data hasil penelitian menggunakan metode deskriptif dan eksploratif. Metode deskriptif digunakan untuk menganalisis hasil angket dari responden tentang strategi pengembangan perpusta-kaan Fakultas Ilmu Pendidikan yang ditinjau dari ketersediaan sarana dan pemanfaatan bahan pustaka, pengelolaan perpustakaan Fakultas Ilmu Pendidikan. Metode eksploratif digunakan untuk menganalisis hasil wawancara dari responden tentang strategi pengembangan perpustakaan secara ideal. Dari analisis tersebut akan dimunculkan sebuah kesimpu-lan mengenai harapan mahasiswa terhadap pengem-bangan perpustakaan.

\section{Deskripsi Objek Penelitian}

Penelitian ini dilakukan pada perpustakaan di Fakultas Ilmu Pendidikan UNJ. Adapun visi dan misi perpustakaan Fakultas Ilmu Pendidikan adalah Visi: Menjadikan perpustakaan Fakultas Ilmu Pendidikan sebagai pusat pengembangan pendidikan yang berbasis teknologi informasi dan komunikasi (TIK), Misi: (1) Mengembangkan bahan koleksi perpustakaan menyediakan sarana pendukung perpustakaan berbasis teknologi informasi dan komunikasi (TIK) (2) Memberikan layanan prima kepada stakeholders.

Visi dan misi di atas sesuai dengan semangat Undang-undang Perpustakaan Nomor 43 Tahun 2007 bahwa perpustakaan perguruan tinggi mengembang-kan layanan perpustakaan berbasis teknologi informasi dan komunikasi.

\section{Deskripsi Data}

1. Ketersediaan Sarana dan Pemanfaatan Bahan Pustaka

Pada aspek ketersediaan sarana dan peman-faatan bahan pustaka, terdapat tiga indikator yang dinilai, yaitu ketersediaan fasilitas, ketersediaan bahan pustaka, dan pemanfaatan perpustakaan.

a. Keberadaan Perpustakaan

Dari 120 responden 98.3\% menjawab bahwa keberadaan perpustakaan FIP sangat diperlukan mahasiswa. Data tersebut dapat divisualisasikan pada gambar berikut.

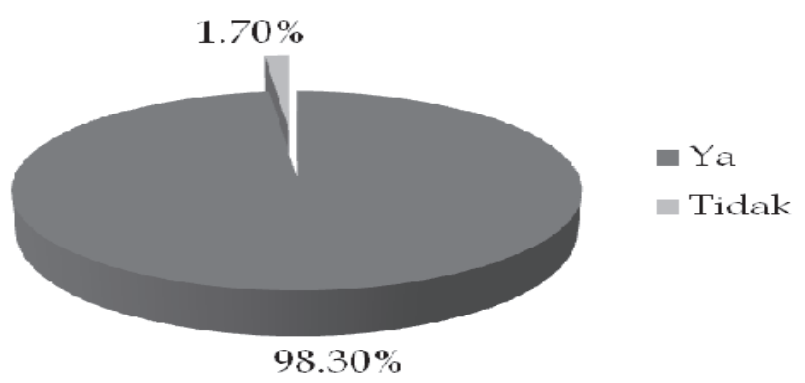

Gambar 2. Persentase Pentingnya Keberadaan Perpustakaan FIP

b. Pada aspek ketersediaan fasilitas perpustakaan

Dari 120 responden sebanyak 55.8\% responden menjawab bahwa perpustakaan belum dilengkapi dengan fasilitas yang memadai dan $44.2 \%$ menjawab sebaliknya. Data tersebut dapat divisualisasikan pada gambar berikut.

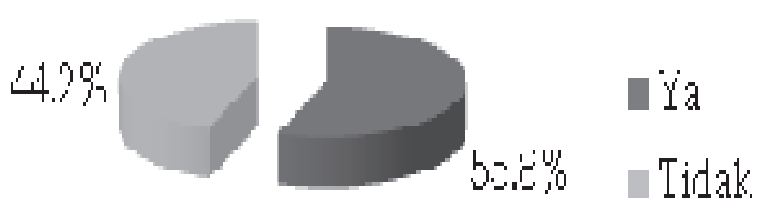

Gambar 3. Persentase Ketersediaan Fasilitas Perpustakaan

Data ini menunjukkan bahwa fasilitas perpus-takaan FIP belum memadai. 
c. Kelengkapan Bahan Pustaka.

Dalam hal kelengkapan bahan pustaka, dari 120 responden $70.8 \%$ responden menjawab tidak mudah menemukan buku yang dicari. Data tersebut dapat divisualisasikan pada gambar berikut.
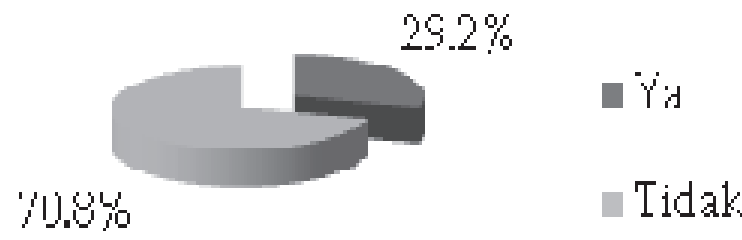

Gambar 4. Persentase Kelengkapan Bahan Pustaka

d. Pemanfaatan Perpustakaan

Dari 120 responden sebanyak 59.8\% responden menjawab bahwa perpustakaan belum dimanfaatkan dengan baik oleh mahasiswa dan $40.2 \%$ responden menjawab perpustakaan FIP sudah dimanfaatkan dengan baik oleh mahasiswa. Data tersebut dapat divisualisasikan pada gambar berikut.

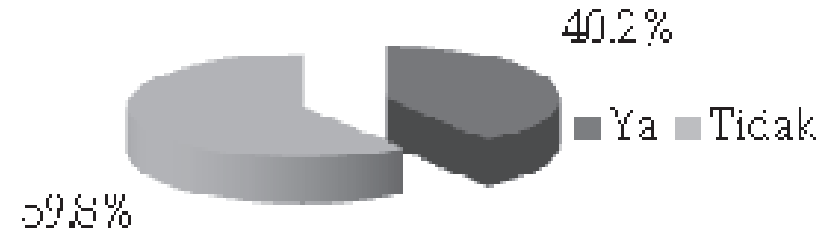

Gambar 5. Persentase Pemanfaatan Perpustakaan

2. Pengelolaan Perpustakaan Fakultas Ilmu Pendi-dikan

Pada aspek pengelolaan perpustakaan FIP terdapat tiga indikator yang dinilai, yaitu pelayanan perpustakaan, kelengkapan bahan pustaka, kerapihan penataan perpustakaan, dan perawatan perpustakaan a. Pelayanan Perpustakaan

Dari 120 responden $48.3 \%$ menjawab bahwa pelayanan yang dirasakan mahasiswa di perpusta-kaan FIP belum sesuai dengan harapan mahasiswa dan 51.7\% responden menjawab bahwa pelayanan yang dirasakan mahasiswa di perpustakaan FIP sesuai dengan kebutuhan mahasiswa. Data tersebut dapat divisualisasikan pada gambar berikut.
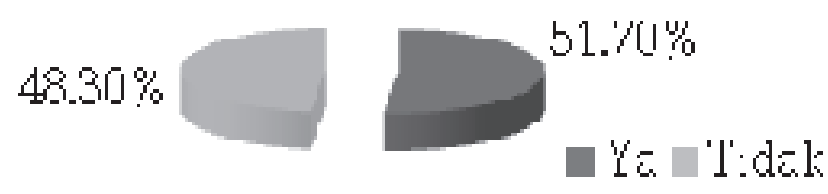

Gambar 6. Persentase Pelayanan terhadap Mahasiswa di Perpustakaan

b. Kelengkapan bahan pustaka

Dari 120 responden 52.4\% menjawab bahwa bahan pustaka yang ada di jurusan belum sesuai dengan kebutuhan mahasiswa dan $47.6 \%$ responden menjawab bahwa bahan pustaka sudah lengkap. Data tersebut dapat divisualisasikan pada gambar berikut.

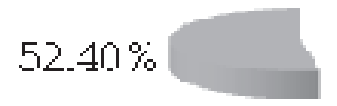

Gambar 7. Persentase Kelengkapan Bahan Pustaka
Hal ini menunjukkan bahwa bahan pustaka di Fakultas Ilmu Pendidikan, baik ketersediaan buku-bu$\mathrm{ku}$, ketersediaan surat kabar dan majalah, maupun ketersediaan buku fiksi dan nonfiksi belum memadai. c. Kerapihan Penataan Perpustakaan

Dari 120 responden $42.4 \%$ menjawab bahwa perpustakaan FIP belum tertata dengan baik dan $47.6 \%$ responden menjawab bahwa perpustakaan FIP sudah tertata dengan baik. Data tersebut dapat divisualisasi-kan pada gambar berikut.
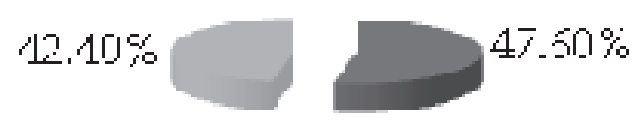

\section{Ya T:dak}

Gambar 8. Persentase Penataan Perpustakaan

Hal ini menunjukkan bahwa penataan perpus-takaan di Fakultas Ilmu Pendidikan sudah cukup baik, namun perlu ditingkatkan lagi agar perpustakaan FIP akan semakin tertata baik.

d. Perawatan Perpustakaan

Dari 120 responden, $62.3 \%$ menjawab bahwa perpustakaan FIP sudah terawat dengan baik dan $37.7 \%$ responden menjawab bahwa perpustakaan FIP belum terawat dengan baik. Data tersebut dapat divisualisasikan pada gambar berikut.

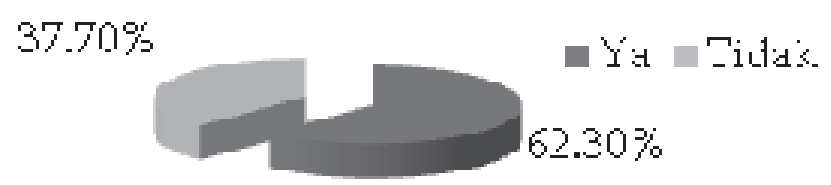

Gambar 9. Persentase Perawatan Perpustakaan

3. Aplikasi Teknologi dalam Pengelolaan dan Pengembangan Perpustakaan

Pada aspek aplikasi teknologi dalam pengelo-laan dan pengembangan perpustakaan FIP, terdapat tiga indikator yang dapat dilihat yaitu penguasaan aplikasi teknologi informasi, sinema perpustakaan, dan sistem otomasi perpustakaan. 
a. Penguasaan Aplikasi Teknologi Informasi

Dari 120 responden, 93.4\% menjawab bahwa penguasaan aplikasi teknologi informasi dalam perpustakaan FIP sangat diperlukan dan 7.6\% respon-den menjawab bahwa penguasaan aplikasi teknologi informasi dalam perpustakaan FIP tidak diperlukan. Data tersebut dapat divisualisasikan pada gambar berikut.

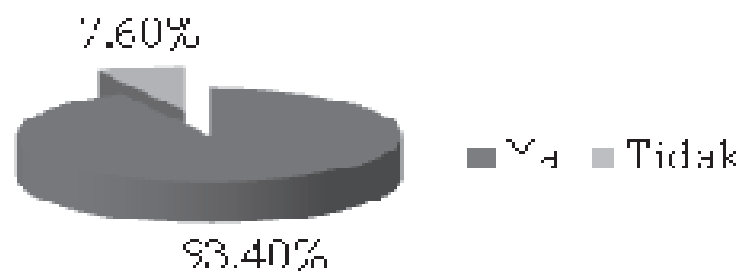

Gambar 10. Persentase Perlunya Penguasaan Aplikasi Teknologi Informasi

b. Sistem Informasi Manajemen (Sinema) Perpusta-kaan Perlu Diterapkan dalam Pengembangan Perpustakaan FIP

Dari 120 responden, $87.8 \%$ menjawab bahwa Sistem Informasi Manajemen di perpustakaan FIP sangat diperlukan dan $12.2 \%$ responden menjawab bahwa Sistem Informasi Manajemen dalam perpusta-kaan FIP tidak diperlukan. Data tersebut dapat divisua-lisasikan pada gambar berikut.

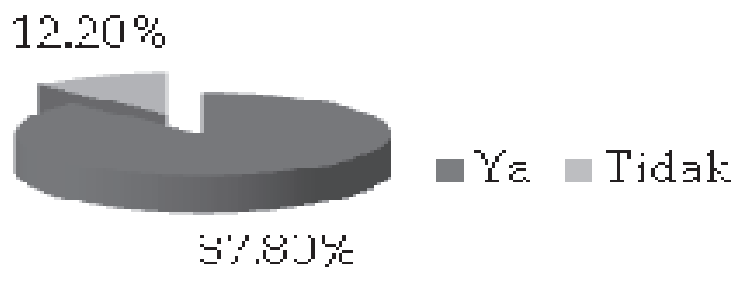

Gambar 11. Persentase Perlunya Sinema di Perpustakaan FIP

c. Perlunya Sistem Otomasi Diterapkan dalam Pengembangan Perpustakaan FIP

Dari 120 responden, 48.6\% menjawab bahwa sistem otomasi di perpustakaan FIP sangat diperlukan dan $41.4 \%$ responden menjawab bahwa sistem otomasi dalam perpustakaan FIP tidak diperlukan. Data tersebut dapat divisualisasikan pada gambar berikut.

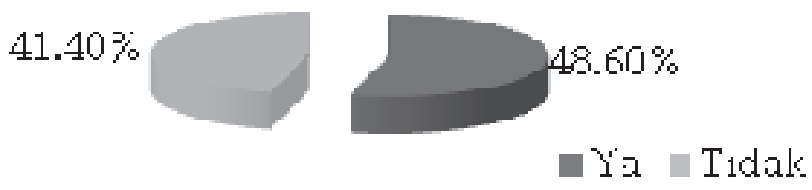

Gambar 12. Persentase Perlunya Sistem Otomasi di Perpustakaan FIP

\section{Partisipasi Mahasiswa}

a. Mahasiswa dapat berperan dalam pengembangan perpustakaan

Dari 120 responden, $67.2 \%$ menjawab bahwa mahasiswa dapat berperan dalam pengembangan perpustakaan FIP dan $32.8 \%$ responden menjawab bahwa mahasiswa tidak perlu berperan dalam pengembangan perpustakaan FIP. Data tersebut dapat divisualisasikan pada gambar berikut.

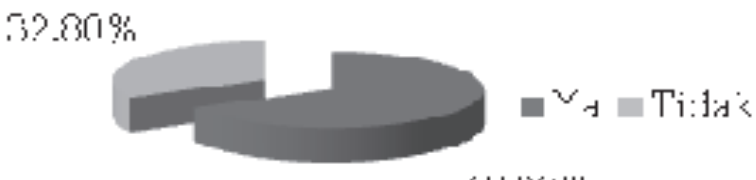

$6 \% .20 \%$

Gambar 13. Persentase Perlunya Mahasiswa Berperan dalam Pengembangan Perpustakaan FIP

b. Mahasiswa dapat memberikan saran dan kritik dalam pengembangan perpustakaan

Dari 120 responden, 84.7\% menjawab bahwa mahasiswa dapat berperan dalam pengembangan perpustakaan FIP dengan mengemukakan saran dan kritik dan $15.3 \%$ responden menjawab bahwa maha-siswa tidak perlu memberikan saran dan kritik dalam pengembangan perpustakaan FIP. Data tersebut dapat divisualisasikan pada gambar berikut.

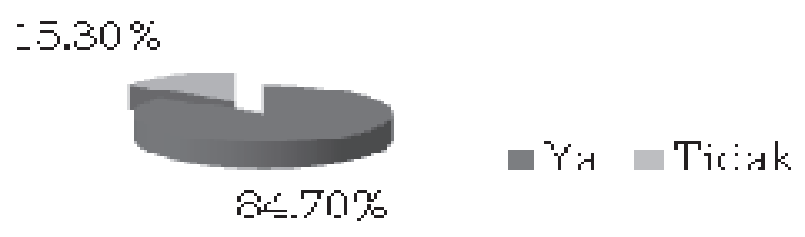

Gambar 14. Persentase Mahasiswa dapat Memberikan Saran dan Kritik dalam Pengembangan Perpustakaan FIP

\section{Analisis Data}

Dari pengolahan data pada aspek ketersediaan sarana dan pemanfaatan bahan pustaka didapatkan data bahwa mahasiswa $98.3 \%$ berpendapat keberada-an perpustakaan Fakultas Ilmu Pendidikan (FIP) UNJ sangat diperlukan dalam menunjang proses pembela-jaran/perkuliahan di FIP UNJ. Untuk itu untuk memak-simalkan keberadaan perpustakaan maka diperlukan berbagaipengembangan dalam beberapa aspeknya.

Aspek ketersediaan fasilitas perpustakaan dinilai mahasiswa sebanyak $55.8 \%$ dari 120 responden belum cukup memadai meskipun sudah ada beberapa fasilitas seperti AC dan komputer tetapi hal itu saja ternyata tidaklah cukup. Begitu pula dalam 
aspek kelengkapan bahan pustaka, 70.8\% dari 120 responden menjawab tidak menemukan bahan atau literatur yang dicari. Hal ini menunjukkan bahwa perpustakaan FIP perlu melengkapi bahan/literatur terutama disesuai-kan dengan perkembangan terbaru dari kebutuhan mahasiswa dan pembaharuan tahun penerbitan dari buku/literatur yang disediakan. Pada aspek peman-faatan perpustakaan sebanyak $59.8 \%$ mahasiswa mengatakan belum mampu maksimalkan pemanfaa-tan perpustakaan karena belum lengkapnya literatur yang dibutuhkan.

Pengelolaan perpustakaan, baik dilihat dari kelengkapan bahan pustaka, pelayanan perpustakaan, dan kerapihan serta perawatan perpustakaan masih perlu dilengkapi dan perbaiki. Ini terlihat dari jawaban responden di mana 52.4\% mengatakan bahwa bahan pustaka yang ada di perpustakaan FIP belum dapat memenuhi kebutuhan perkuliahan mahasiswa. Ini menunjukkan bahwa bahan pustaka di Fakultas Ilmu Pendidikan, baik ketersediaan buku-buku pendidikan, ketersediaan surat kabar dan majalah, maupun ketersediaan buku fiksi dan nonfiksi belum lengkap sehingga perlu ada penambahan koleksi bahan pustaka yang sesuai dengan kebutuhan pengguna.

Kerapihan penataan semua literatur yang ada dan perawatan fasilitas perpustakaan FIP juga masih harus dibenahi. Hal ini didasari tanggapan maha-siswa sebanyak $42.4 \%$ yang menyatakan bahwa penataan perpustakaan belum maksimal. Maka dari itu perlu adanya pengkatalogisasian dan penataan kembali agar dapat tersusun rapi dan mudah ditemu-kan.

Upaya yang dapat dilakukan untuk pengem-bangan perpustakaan FIP adalah dengan diterapkan-nya Sistem Informasi Manajemen Perpustakaan yang harus diikuti oleh penguasaannya oleh pengelola perpustakaan FIP, upaya ini disetujui oleh 93.4\% responden. Upaya lain yang dapat dilakukan yaitu dengan membuat sistem otomasi perpustakaan sehingga mahasiswa mudah menemukan buku yang dicari, di samping memudahkan pengelola perpusta-kaan dalam sirkulasi peminjaman buku. Selain itu, dapat juga dilakukan pemberian motivasi kepada mahasiswa untuk ikut aktif dalam pengembangan perpustakaan FIP dan mendukung hal ini, responden sebanyak $84.7 \%$ menyatakan bersedia berpartisipasi dalam pengembangan perpustakaan FIP UNJ.

\section{PENUTUP}

\section{Kesimpulan}

Berdasarkan hasil penelitian yang telah dilakukan, maka dapat dikemukakan beberapa kesimpulan sebragai berikut. Perspektif llmu Pendidikan - Vol.22 Th. XIII Oktober 2010
Pertama, perpustakaan Fakultas Ilmu Pendidi-kan belum terkelola dengan maksimal, ini dapat dilihat dari ketersediaan koleksi bahan pustaka yang belum lengkap, sebagian besar bahan pustaka belum tertata dengan rapi dan mayoritas bukan terbitan buku terbaru (kurang up to date).

Kedua, ketersediaan sarana sudah cukup lengkap hanya saja perlu penataan ruang kembali sehing-ga dapat lebih nyaman.

Ketiga, aplikasi Teknologi Informasi yang berupa penerapan Sistem Informasi Manajemen Perpustakaan (Sinema Pustaka) dan Sistem Otomasi Perpustakaan adalah upaya yang dapat dijalankan untuk pengembangan perpustakaan.

Keempat, partisipasi mahasiswa dapat diupa-yakan dengan pemberian motivasi agar mau berparti-sipasi dalam pengembangan perpustakaan.

\section{Saran}

Beberapa saran yang dapat diajukan dalam penelitian ini sebagai berikut.

Pertama, pengelolaan perpustakaan perlu ditingkatkan dengan berbagai upaya yang dapat direncanakan dengan baik.

Kedua, penataan ulang ruangan dan penamba-han beberapa fasilitas perpustakaan harus segera dilakukan. Demikian juga halnya dengan penamba-han koleksi dan pengurangan koleksi yang sudah terlalu lama.

Ketiga, penerapan aplikasi teknologi informasi dengan penerapan Sistem Informasi Manajemen Perpustakaan (Sinema Pustaka) dan penerapan sistem otomasi perpustakaan perlu segera dirancang untuk memudahkan pencarian buku karena sudah terkom-puterisasi.

Keempat, perlu diupayakan penyelenggaraan event-event tertentu untuk memotivasi mahasiswa khususnya dan civitas akademik lain pada umumnya untuk lebih peduli dengan keberadaan perpustakaan Fakultas Ilmu Pendidikan. Event ini antara lain seperti diselenggarakannya acara Bulan Peduli Perpustakaan yang inti kegiatannya dapat meliputi : gerakan hibah buku, gerakan koin perpustakaan, lomba penulisan artikel tentang pengembangan perpustakaan, dan lain-lain.

\section{DAFTAR PUSTAKA}

Arnstein, S.R. (2008). A ladder of citizen participation. Diakses pada tanggal 20 April 2008 dari http:/ / goodspeedupdate.com/2008/2224" \o "Public Participation Theory". 
Bafadol, I. (2001). Pengelolaan perpustakaan sekolah. Jakarta: Bumi Aksara.

Basuki, S. (1993). Pengantar ilmu perpustakaan. Jakarta: Universitas Terbuka.

Davis, K. \& Newstrom, J.W. (1992). Perilaku dalam organisasi. Terjemahan: Agus Dharma. Jakarta: Erlangga.

Fattah, N. (2003). Konsep manajemen berbasis sekolah dan dewan sekolah. Bandung: Pustaka Bany Quraisy.

Gasperz, V. (2002). Total quality management. Jakarta: Gramedia.

Koentjaraningrat. (1993). Kebudayaan mentalitas dan pembangunan. Jakara: Gramedia Pustaka Utama.

Margono, S. (1985). Meningkatkan partisipasi masyarakat dalam pembangunan pedesaan. Jakarta: Interaksi No.1, thn 1, 1985.

Mulyasa, E. (2003). Menjadi kepala sekolah profesional. Bandung: PT. Remaja Rosdakarya.

Porang, I.S. (1990). Peranan perpustakaan dan manfaat membaca buku. Jakarta: Media Pendidikan.

Rhiti, H. (2005). Kompleksitas permasalahan lingkungan hidup. Yogyakarta: Universitas Atma Jaya.

Roes, J.E. (1995). Total quality management. Singapore: Mubarok and Brothers.

Shaleh, A.R. I.A. (1987). Penyelenggaraan perpustakaan sekolah. Jakarta: Hidayakarta Agung.

Soeatminah. (1991). Perpustakaan, kepustakawanan, dan pustakawan. Yogyakarta: Kanisius.
Rochaety, E., dkk. (2005). Sistem informasi manajemen pendidikan. Cetakan Pertama. Jakarta: Bumi Aksara.

Soedibyo, N. (1988). Pengelolaan perpustakaan. Bandung: Alumni.

Stamatis, D.H. (1977). Total quality service. New Delhi: Vanity Book International.

Stanly, L.G. \& Davis, B. (1997). Introduction to total quality. New Jersey: Prentice Hall.

Stoner, J.A.F. (1978). Management. USA: Prentice Hall. Inc.

Sumadji, P. (1992). Perpustakaan: Organisasi dan tata kerjanya. Yogyakarta: Kanisius.

Supranto. (2001). Pengukuran tingkat kepuasan pelanggan. Jakarta: Rineka Cipta.

Sutarno. (2003). Perpustakaan dan masyarakat. Jakarta: Yayasan Obor Indonesia.

World Bank. Participation learning group final report. Diakses pada tanggal 12 Januari 2009 dari http://www.worldbank.org/wbi/sourcebook/ sb0100.html.

\section{KETERANGAN PENULIS}

Siti Zulaikha, lahir di Cianjur pada tanggal 20 April 1974. Saat ini bertugas sebagai Dosen Manajemen Pendidikan FIP UNJ. 